\title{
Credit Risk and Bank Credit Behavior under the New Normal Economy
}

\author{
Lei Pang ${ }^{1, a}$, Guangbin Zhang ${ }^{2, b^{*}}$
}

${ }^{1}$ School of Economics and management, Yunnan Normal University, Kunming 650500, China;

${ }^{2}$ School of Economics and management, Yunnan Normal University, Kunming 650500, China.

apanlgei719@126.com, b673076750@qq.com

${ }^{*}$ Corresponding author

Keywords: Credit risk, Bank credit behavior, New normal economy.

\begin{abstract}
Macroeconomic volatility and bank credit influence each other, the relationship between them attracted a wide spread attention after the financial crisis in 2008. Thus this paper did the research on Credit risk and bank credit behavior of our country. We found that the credit risk has a pro-cyclical characteristic in China. The results show that:(1) the pro-cyclicality of credit risk on large banks are more obvious than City Commercial Bank; (2) the adjustment of provision for loan loss reserve to credit growth is counter-cyclical. Further study found that counter-cyclical performance of large banks was not significant, City Commercial Bank's loan loss provisioning for loan growth of counter-cyclical adjustment mechanism are obvious. This paper recommends to take counter-cyclical loan loss reserve management measures and non-discretionary manner to deal with the risk of bank credit.
\end{abstract}

\section{Introduction}

Under the new normal economy, China's economy has shown the feature of "a reasonable range of adjustment of economic structure and stable growth ", facing a "manufacturing to production, to the inventory of real estate, to government debt, financial deleveraging" and other issues, Xi Jinping remedy proposed "supply-side structural reforms." Under the new normal economy, China's banking credit has the emergence of new features and performance. Under the new normal economy, whether the characteristics of credit is procyclical? The Paper uses empirical approach to verify the existence of three channels and whether is the impact mechanism smooth. These studies have important theoretical and practical significance for China's banking industry, may help understanding the credit and stable operation of the financial and research support and provide some theoretical guidance for China's policy makers.

\section{Model Specification}

This part mainly researches two problems, one is to test whether the bank credit risk owns a pro-cyclical characteristic, the other is the impact of bank credit risk of periodic performance on bank credit growth.

\subsection{Bank credit risk pro-cyclical testing}

This paper use the reference of Wang et al. (2013) ${ }^{1}$ to build this model:

$$
\begin{aligned}
\ln l l p_{i, t} & =\alpha_{0}+\alpha_{1} \ln l l p_{i, t-1}+\alpha_{2} \ln \operatorname{asset}_{i, t}+\alpha_{3} l r_{i, t}+\alpha_{4} \operatorname{cadr}_{i, t}+\alpha_{5} r c_{i, t} \\
& +\alpha_{6} m 2 g r_{t}+g d p g r_{t}+\theta_{t}+\varepsilon_{i, t}
\end{aligned}
$$

Among them $i=1,2,3 \cdots \cdots$, represents bank individual, $t$ represents years. In this paper, we have categorized all banks into three groups to do empirical research, the first group for all banks, the second group for large banks consist of listed state-owned banks and joint-stock commercial banks, the third group for all rest bank including the city commercial banks.

\footnotetext{
${ }^{1}$ Wang. Leverage pro-cyclical and its influence on bank balance sheets - based on an empirical analysis of the 161 Banks in our country [J]. Shanghai Finance, 2013(10):33-40.
} 
Furtherly, in order to analyze the bank credit risk management of changes in the bank loan growth, we have built the following models:

$$
\begin{aligned}
{\text { dif } \ln \text { loan }_{i, t}} & \alpha_{0}+\alpha_{1} \text { dif } \ln \operatorname{loan}_{i, t-1}+\alpha_{2} \ln \text { llp }_{i, t}+\alpha_{3} \ln \text { asset }_{i, t}+\alpha_{4} l_{i, t} \\
& +\alpha_{5} \text { cadr }_{i, t}+\alpha_{6} r_{i, t}+\alpha_{7} m 2 \text { gr }_{t}+\alpha_{8} \text { gdpgr }_{t}+\theta_{t}+\varepsilon_{i, t}
\end{aligned}
$$

Among them $\mathrm{i}=1,2,3 \cdots \cdots$, represents bank individual, $\mathrm{t}$ represents years. This paper also categorized all banks in model 2 to do regression.

\subsection{Variable declaration and descriptive statistics}

This paper selected bank credit risk and credit growth as dependent variables, Banks microscopic characteristics variables, monetary policy and macro economy proxy variables as explanatory variables. In this paper, the research data is unbalanced panel data for 126 Banks in 1999-2014.

Table1 Variable declaration and descriptive statistics

\begin{tabular}{c|c|c|c|c|c|c|c}
\hline variable name & proxy variable & Variable & obs & mean & sd & min & $\max$ \\
\hline Loan growth & Rate of loan growth & Rlg & 1004 & 0.21 & 0.16 & -0.46 & 2.78 \\
\hline \multirow{2}{*}{ Credit risk } & Loan loss provision & lnllp & 1080 & 13.9 & 2.02 & 4.61 & 20.4 \\
\cline { 2 - 8 } & non-performing loan ratio & nplr & 1077 & 3.85 & 8.23 & 0.01 & 50.2 \\
\hline scale of bank & Total Bank assets & lnasset & 1153 & 18.4 & 1.74 & 14.4 & 2.75 \\
\hline liquidity & Liquidity ratio & lr & 1067 & 27.1 & 12.5 & 0.00 & 29.1 \\
\hline Capital adequacy & Capital adequacy ratio & cadr & 1160 & 12.1 & 13.5 & -1.47 & 46.0 \\
\hline profitability & Return on capital & rc & 1168 & 15.0 & 28.0 & -4.20 & 77.8 \\
\hline Monetary policy & M2 growth rate & m2gr & 2144 & 16.3 & 3.72 & 12.2 & 27.7 \\
\hline macroeconomic & GDP growth rate & gdpgr & 2144 & 9.50 & 1.81 & 7.27 & 14.1 \\
\hline
\end{tabular}

Data sources: bankscope database、 wind database.

Table 2 correlation coefficient matrix

\begin{tabular}{c|c|c|c|c|c|c|c|c}
\hline & Rlg & lnllp & nplr & lnasset & lr & cadr & rc & m2gr \\
\hline Inllp & $-0.208^{* * *}$ & & & & & & & \\
\hline nplr & -0.035 & 0.019 & & & & & & \\
\hline lnasset & $-0.159^{* * *}$ & $0.835^{* * *}$ & $0.113^{* * *}$ & & & & & \\
\hline $\mathrm{lr}$ & 0.038 & -0.010 & $-0.121^{* * *}$ & -0.020 & & & & \\
\hline $\mathrm{cadr}$ & $0.129^{* * *}$ & $-0.112^{* * *}$ & $-0.123^{* * *}$ & $-0.056^{* *}$ & $0.080^{* *}$ & & & \\
\hline $\mathrm{rc}$ & -0.010 & $-0.079^{* * *}$ & $0.095^{* *}$ & $0.071^{* *}$ & $0.058^{*}$ & -0.036 & & \\
\hline $\mathrm{m} 2 \mathrm{gr}$ & $0.188^{* * *}$ & $-0.112^{* * *}$ & 0.048 & $-0.120^{* * *}$ & -0.005 & -0.032 & 0.006 & \\
\hline gdpgr & 0.033 & $-0.224^{* * *}$ & $0.081^{* * *}$ & $-0.242^{* * *}$ & $-0.115^{* * *}$ & $-0.049^{*}$ & 0.020 & $0.322^{* * *}$ \\
\hline
\end{tabular}

Note: $*$ 、**,***, represents in $10 \%, 5 \%$ and $1 \%$ significance level.

The source of all the bank data and macroeconomic variable data comes from Bankscope and Wind database separately. Table1 is the description of all variables statistics and table 2 is the correlation coefficient matrix for all variables.

\section{Regression results analysis}

This paper used the dynamic panel estimation model and dependent variable first-order lag in order to solve Endogenous problems. Table 3 is the estimation results of the model 1,we draw the following conclusions: Firstly, the bank's credit risk has pro-cyclical known by gdpgr with lnllp correlation coefficient is positive. Secondly bank assets and bank credit risk is inversely proportional. When bank assets larger, credit scale will also rise, and vice versa. The third is that M2 growth rate and credit risk shows positive relationship, therefore, as the M2 growth rate increase at the same time, the bank's credit risk also rose. 
Table3 Regression results of Credit risk pro-cyclical inspection group

\begin{tabular}{cccc}
\hline & \multicolumn{3}{c}{ dependent variables: Credit risk lnllp } \\
\hline & $(1)$ - All banks & $(2)$ - large banks & (3)- City commercial banks \\
\hline L.Inllp & $0.538^{* * *}$ & $0.256^{* *}$ & $0.679^{* * *}$ \\
& $(81.49)$ & $(2.40)$ & $(40.21)$ \\
lnasset & $0.412^{* * *}$ & $0.515^{* * *}$ & $0.319^{* * *}$ \\
& $(39.87)$ & $(5.01)$ & $(17.06)$ \\
lr & $-0.004^{* * *}$ & $-0.003^{* * *}$ & 0.000 \\
& $(-18.96)$ & $(-2.58)$ & $(0.51)$ \\
cadr & $0.012^{* * *}$ & 0.010 & $0.014^{* * *}$ \\
& $(7.92)$ & $(0.78)$ & $(3.64)$ \\
rc & $0.128^{* * *}$ & $0.620^{* * *}$ & $0.019^{*}$ \\
& $(13.91)$ & $(4.16)$ & $(1.93)$ \\
m2gr & $-0.006^{* * *}$ & -0.002 & $-0.004^{* * *}$ \\
& $(-18.95)$ & $(-0.23)$ & $(-9.02)$ \\
gdpgr & $0.017^{* * *}$ & $0.028^{* * *}$ & $0.014^{* * *}$ \\
& $(15.46)$ & $(3.24)$ & $(8.45)$ \\
cons & $-1.045^{* * *}$ & 1.146 & $-1.149^{* * *}$ \\
& $(-9.54)$ & $(1.43)$ & $(-7.46)$ \\
N & 726 & 218 & 508 \\
AR (1) & 0.0613 & 0.1046 & 0.0076 \\
AR (2) & 0.9436 & 0.758 & 0.2756 \\
sargan & 0.8558 & 1.0000 & 0.9565 \\
\hline
\end{tabular}

Note: *,**,***, represents in $10 \%, 5 \%$ and $1 \%$ significance level.

The results of regression of table 4 draw the following conclusions: Firstly, Loan loss provisions prescribed in a negative correlation relationship with bank lending growth. when loan loss provision becomes much more, the credit risk of bank will become smaller. It has inhibitory effect to bank credit risk. Secondly, the scale of bank assets will inhibit growth of bank credit loan. The asset size of credit growth inhibitory effect of Large Banks is more apparent than city commercial bank. The third is that M2 growth rate and good macro environment has a promoting effect for bank credit growth. 
Table4 Credit risk management of bank loan growth change relation dependent variables: Credit loan growth

\begin{tabular}{cccc}
\hline & $(1)$-All banks & (2)-Large banks & (3)-City commercial banks \\
\hline L.Rlg & $0.265^{* * *}$ & $0.258^{* * *}$ & $0.320^{* * *}$ \\
& $(54.93)$ & $(3.19)$ & $(21.96)$ \\
Lnllp & $-0.014^{* * *}$ & 0.012 & $-0.016^{* * *}$ \\
& $(-4.56)$ & $(0.86)$ & $(-5.45)$ \\
lnasset & $-0.021^{* * *}$ & $-0.079^{* * *}$ & 0.004 \\
& $(-5.04)$ & $(-4.21)$ & $(1.12)$ \\
lr & $-0.002^{* * *}$ & 0.000 & $-0.002^{* * *}$ \\
& $(-6.53)$ & $(0.21)$ & $(-5.52)$ \\
cadr & $0.004^{* * *}$ & $0.005^{* *}$ & $0.004^{* * *}$ \\
& $(16.35)$ & $(2.43)$ & $(14.45)$ \\
rc & 0.007 & -0.021 & 0.006 \\
& $(1.65)$ & $(-0.46)$ & $(1.31)$ \\
m2gr & $0.007^{* * *}$ & $0.021^{* * *}$ & $0.006^{* * *}$ \\
& $(132.56)$ & $(8.49)$ & $(83.56)$ \\
gdpgr & $0.007^{* * *}$ & $0.005^{* *}$ & 0.000 \\
& $(14.56)$ & $(2.49)$ & $(0.07)$ \\
cons & $0.556^{* * *}$ & $1.554^{* * *}$ & $0.186^{* * *}$ \\
& $(14.45)$ & $(3.12)$ & $(3.16)$ \\
\hline $\mathrm{N}$ & 645 & 202 & 443 \\
AR (1) & 0.0000 & 0.0256 & 0.0000 \\
AR (2) & 0.9469 & 0.7468 & 0.9463 \\
sargan & 0.7235 & 1.0000 & 0.9435 \\
\hline
\end{tabular}

Note: $*$ 、**、***, represents in $10 \%, 5 \%$ and $1 \%$ significance level.

\section{Summary}

This article used the domestic 134 Banks in 1999-2014 and the unbalanced panel data to set up the dynamic panel regression model, through using difference GMM method to do empirical analysis on bank credit loan and bank credit risk behavior. We draw the following conclusions: (1) the bank credit risk has the pro-cyclical. (2) the loan loss provisions make reverse adjustment with periodic on credit growth. (3) the micro bank characteristics and monetary policy has inhibitory effect on bank credit risk. (4) the loose monetary policy and the improvement of GDP growth is helpful to stimulate the bank's credit growth.

\section{References}

[1] Alexeev M, Kim S. The Korean financial crisis and the soft budget constraint[J]. Journal of Economic Behavior \& Organization, 2008, 68(1): 178-193.

[2] Anderson R C, Fraser D R. Corporate control, bank risk taking, and the health of the banking industry[J]. Journal of Banking \& Finance, 2000, 24(8): 1383-1398.

[3] Ando A, Modigliani F. The "Life Cycle" Hypothesis of Saving: Aggregate Implications and Tests[J]. American Economic Review, 1963, 53(1):55-84.

[4] Claessens S, Laeven L. Financial Dependence, Banking Sector Competition, and Economic Growth[J]. Journal of the European Economic Association, 2005, 3(3):179-207.

[5] Duffie D, Ziegler A. Liquidation risk[J]. Financial Analysts Journal, 2003, 59(3): 42-51.

[6] Gunji H, Miura K, Yuan Y. Bank competition and monetary policy[J]. Japan \& the World Economy, 2009, 21(1):105-115. 
[7] Kashyap A, Stein J, Wilcox D. The monetary transmission mechanism: Evidence from the composition of external finance[J]. American Economic Review, 1993, 83(1): 78-98.

[8] La Porta R, Florencio L D S, Shleifer A, et al. Investor Protection and Corporate Governance[J]. Journal of Financial Economics, 1999,56(3): 23-32..

[9] Salas V, Saurina J. Credit Risk in Two Institutional Regimes: Spanish Commercial and Savings Banks[J]. Journal of Financial Services Research, 2002, 22(3):203-224.

[10]Tsui, Auch, LS. International production relationships and developmental impacts. International Journal of Urban \& Regional Research1999,23 （2） : 345-359.

[11] John Humphrey, Upgrading in global value chains, Working Paper No. 28,2004, ISBN 92-2-116015-7 (printed version),Policy Integration Department of World Commission on the Social Dimension of Globalization International Labor Office.

Yunnan Normal University PhD Project Number: Chinese Enterprises Overseas M\&A and Home Technology Strategy Research under One Belt and One Road(160025). 